[Vol. 128:622

\title{
COMMENTS
}

\section{VERTICAL AGREEMENT AS HORIZONTAL RESTRAINT: CERNUTO, INC. V. UNITED CABINET CORP.}

In Continental T.V., Inc. v. GTE Sylvania Inc., the Supreme Court overruled prior case law ${ }^{2}$ and held that a location restriction imposed by a manufacturer on the distribution of its product was not a per se violation of section 1 of the Sherman Act. ${ }^{3}$ Although courts ${ }^{4}$ and commentators ${ }^{5}$ alike have struggled with Sylvania's exact meaning and reach, its broad import is to require that vertical restraints ${ }^{6}$ be governed generally ${ }^{7}$ by a rule of

1433 U.S. 36 (1977).

2 United States v. Amold, Schwinn \& Co., 388 U.S. 365 (1967) (holding territorial and choice-of-customer restrictions illegal per se).

315 U.S.C. $\$ 1$ (1976).

4 See, e.g., Sherman v. British Leyland Motors, Ltd., 601 F.2d 429 (9th Cir. 1979) (territorial division of automobile markets); Smith v. Pro Football, Inc., 593 F.2d 1173 (D.C. Cir. 1978) (football draft); Gough v. Rossmoor Corp., 585 F.2d 381 (9th Cir. 1978), cert. denied, 440 U.S. 936 (1979) (newspaper advertising access); Dougherty v. Continental Oil Co., 579 F.2d 954 (5th Cir. 1978) (jobbers purchase of manufacturer marketing facilities); H \& B Equip. Co. v. International Harvester Co., 577 F.2d 239 (5th Cir. 1978) (company store); Eastern Scientific Co. v. Wild Heerbrugg Instruments, Inc., 572 F.2d 883 (1st Cir.), cert. denied, 439 U.S. 833 (1978) (territorial restriction enforced by price restraints); General Beverage Sales Co. v. East-Side Winery, 568 F.2d 1147 (7th Cir. 1978) (sales territory).

- See, e.g., Bohling, A Simplified Rule of Reason for Vertical Restraints: Integrating Social Goals, Economic Analysis and Sylvania, 64 Iowa L. Rev. 461, 463 n.12 (1979) (listing articles and notes on Sylvania); Williamson, Assessing Vertical Market Restrictions: Antitrust Ramifications of the Transaction Cost Approach, 127 U. PA. L. Rev. 953 (1979); Comment, A Proposed Rule of Reason Analysis for Restrictions on Distribution, 47 FordHaM L. Rev. 527 (1979); Comment, Vertical Agreements to Terminate Competing Distributors: Oreck Corp. v. Whirlpool Corp., 92 HaRv. L. REv. 1160 (1979).

6 "Vertical restraints" generally are restrictions limiting intrabrand competition and are imposed by the manufacturer or other seller on buyers, distributors, or retailers. The vertical restraint in Sylvania was a restriction on the location from which Continental T.V., a retailer, could sell Sylvania products. Other vertical restrictions include customer restrictions, limiting those to whom the products may be resold; exclusive distributorships; grants of areas of primary responsibility; and profit pass-over agreements. See generally ABA ANTrtrust Section, Vertical Restrictions Limtring Intrabrand Competition 3-4, 20-25 (Monograph No. 2, 1977) [hereinafter cited as Vertical Restructrons]; P. AReeda, ANTitrust ANalysis 498-656 (2d ed. 1974); L. Schwartz \& J. FlynN, Antitroust and Regulatory ALternatives 999-1156 (5th ed. 1977).

7 Vertical price fixing is one truly vertical restraint that remains subject to per se treatment. See National Auto Brokers Corp. v. General Motors Corp., 572 F.2d 953 (2d Cir. 1978). But see Note, The Future of the Per Se Rule Against Vertical Price Restrictions, 12 GA. L. REv. 612 (1978) [hereinafter cited as Future of the 
reason. ${ }^{8}$ As a result, use of the rule of reason ${ }^{\circ}$ has expanded, while the importance of the rule of per se illegality has diminished, in challenges to vertical restraints under section 1 of the Sherman Act. ${ }^{10}$

Countering this trend, the Court of Appeals for the Third Circuit narrowed Sylvania in Cernuto, Inc. $v$. United Cabinet Corp.11 by giving a limited meaning to the term "vertical re-

Per Se Rule]. This continued use of a per se rule may be attributable to the courts' conviction that price fixing, however and for whatever reason imposed, is wholly without redeeming virtue. Although vertical price fixing may very well be endowed with competitive attributes, see R. PosNER, ANTITRUST LAw 148-49 (1976), respect for the allocatory and regulatory functions of the price mechanism have induced courts to refrain from even considering the reasonableness of vertical price fixing. See National Soc'y of Professional Eng'rs v. United States, 435 U.S. 679, 692 (1978) (price mechanism is the "central nervous system of the economy" ) (quoting United States v. Socony-Vacuum Oil Co., 310 U.S. 150, 226 n.59 (1940)). Courts likely believe also that the undesirable effects of vertical price fixing are not limited to the reduction of intrabrand price competition. See White Motor Co. v. United States, 372 U.S. 253, 268 (1963) (Brennan, J., concurring) ("Resale price maintenance is not only designed to, but almost invariably does in fact, reduce price competition not only among sellers of the affected product, but quite as much between that product and competing brands.") (emphasis in original).

The Court has suggested that other "applications of vertical restrictions might justify per se prohibition." Continental T.V., Inc. v. GTE Sylvania Inc., 433 U.S. $36,58(1977)$.

${ }^{8}$ For a recent exposition on the per se rule and the rule of reason, see National Soc'y of Professional Eng'rs v. United States, 435 U.S. 679, 687-92 (1978). Professional Engineers advances an effects-oriented rule of reason, which seems to narrow the discretionary rule articulated by Justice Brandeis in Chicago Bd. of Trade v. United States, 246 U.S. 23I, 238 (1918). Although Sylvania relied upon Chicago Board of Trade, Continental T.V., Inc. v. GTE Sylvania Inc., 433 U.S. 36, 49 n.15 (1977), its view of the rule of reason is consistent with that of Professional Engineers, 435 U.S. at 691 n.17.

Justice Stevens's opinion in Professional Engineers summarized the per se and rule of reason methods of analysis:

There are ... two complementary categories of antitust analysis.

In the first category are agreements whose nature and necessary effect are so plainly anticompetitive that no elaborate study of the industry is needed to establish their illegality-they are "illegal per se"-in the second category are agreements whose competitive effect can only be evaluated by analyzing the facts peculiar to the business, the history of the restraint, and the reasons why it was imposed.

Id. 692. See Broadcast Music, Inc. v. Columbia Broadcasting Sys., Inc., 441 U.S. 1, 7-10 (1979) ( sui generis conduct unfamiliar to court not per se illegal); Northern Pac. Ry. v. United States, 356 U.S. 1, 5 (1958) (classic formulation of per se rule); L. Suluivan, HandBook of the LAW of AntrTrust, $\$ \$ 63-67$ (1977).

- See, e.g., National Auto Brokers Corp. v. General Motors Corp., 572 F.2d 953, 960 (2d Cir. 1978) (except for price fixing, all vertical restraints governed by rule of reason); Eastern Scientific Co. v. Wild Heerbrugg Instruments, Inc., 572 F.2d 883 (Ist Cir.), cert. denied, 439 U.S. 833 (1978) (rule of reason applied to resale-price maintenance); General Beverage Sales Co. v. East-Side Winery, 568 F.2d 1147, 1153 (7th Cir. 1978) (Sylvania intended to change more of the law than that pertaining only to location clauses); Hoden Co. v. Johns-Manville Sales Corp., 459 F. Supp. 1250 (N.D. Tex. 1978) (resale-price maintenance).

1015 U.S.C. $\$ 1$ (1976), which provides in pertinent part: "Every contract, combination ... or conspiracy, in restraint of trade or commerce . . . is declared to be illegal."

11595 F.2d 164 (3d Cir. 1979). 
straint." The Third Circuit ruled in Cernuto that a terminated distributor could bring suit against its former supplier on the theory that the latter's conduct was illegal per se. ${ }^{12}$ The court, reversing the district court's order of summary judgment for defendants, held that a per se rule would apply if the plaintiff could prove that its termination was the result of pressure from a competing distributor seeking to escape the plaintiff's price competition. In reaching this conclusion, the court did not consider only the vertical form of the restraint, but instead viewed the purported conspiracy in terms of its horizontal purpose and impact on the distributor level. ${ }^{13}$

This Comment will examine the validity, under Sylvania, of the treatment of vertical arrangements with underlying horizontal purposes as horizontal restraints. The application of this method of analysis in the circumstances alleged in Cernuto-a simple agreement between one manufacturer and one distributor to terminate a competing distributor-will also be considered. If an ostensibly vertical restraint is in fact prescribed by a competitor of the target, the vertical aspects of the situation should not deter a court from focusing on the horizontal purpose. Such a purpose does not characterize the "vertical" restraints contemplated in Sylvania. Rather, this type of restraint is more accurately termed "horizontal" and as such is properly subject to a per se rule.

\section{Cernuto, Inc. v. United Cabinet Corp.}

Cernuto, Inc. is a Western Pennsylvania discount retailer of supplies and appliances used in the construction and remodeling of buildings. In 1974, a cabinet manufacturer, United Cabinet Corporation, agreed to supply Cernuto for at least a two-year period with kitchen cabinets for resale. Cernuto agreed to promote, display, and sell United's cabinets. Three months later, Robert L. Lappin Company, sales representative for United, informed Cernuto that United would no longer supply Cernuto with cabinets. ${ }^{14}$ Cernuto brought suit in the United States District Court for the Western District of Pennsylvania ${ }^{15}$ and asserted, inter alia, ${ }^{16}$ a viola-

12 Id. 170.

13 Id. 168.

14 Id. 165. 1978).

15 Cernuto, Inc. v. United Cabinet Corp., 448 F. Supp. 1332, 1333 (W.D. Pa.

16 Plaintiff set forth five other counts predicated on alleged contract rights and one count alleging unfair trade practices. Id. 1333. 
tion of section 1 of the Sherman Act. ${ }^{17}$ Cernuto alleged that United terminated its distributorship because Famous Furnace \& Supply Company, a retail store selling United cabinets in the same market as Cernuto, had complained to United that Cernuto "was selling United products in Famous' territory" and that Cernuto "was a low price volume dealer." 18

Defendants United and Lappin, moving for summary judgment, argued that Cernuto had failed to assert that its termination unreasonably restrained trade. ${ }^{19}$ Cernuto did not allege, and apparently could not prove, that the termination had produced an actual anticompetitive impact on the sale of cabinets in Western Pennsylvania. ${ }^{20}$ Rather, its claim rested entirely on the illegality per se of the combination among United, Lappin, and Famous..21 The district court granted summary judgment for defendants; ${ }^{22}$ it ruled that Cernuto could not establish a per se violation because the challenged termination did not involve boycotting, vertical price fixing, or horizontal price fixing. ${ }^{23}$

The court of appeals reversed. In an opinion for a unanimous court, Judge Adams wrote:

Given the alleged anti-competitive and arguably horizontal impact of United's decision, and given the price orientation of the alleged conspiracy, we cannot say that a per se violation of the Act may not be shown. If Cernuto can prove at trial that United, Lappin and Famous con-

1715 U.S.C. $\$ 1$ (1976).

18448 F. Supp. at 1334. This Comment does not address specifically whether price stabilization or elimination of "free riders" (discounters that take a free ride on the promotion paid for by full-price retailers) are legal. See R. PosNER, supra note 7, at 165-66. Price stabilization, even if resulting only from the elimination of "free riders," is similar to a "naked" price restraint, see L. Sullivan, supra note 8, at $\$ \$ 73-76$, and cannot be excused by its "reasonableness." See United States v. Trenton Potteries Co., 273 U.S. 392 (1927). Furthermore, elimination of discounters is contrary to the social values of efficiency and low price, see Pitofsky, The Sylvania Case: Antitrust Analysis of Non-Price Vertical Restrictions, 78 Colun. L. Rev. 1, 21-22 (1978), and widespread elimination of discounters may seriously impair the dynamics of the retail industry. Cf. Bliss, Schumpeter, the "Big" Disturbance and Retailing, 39 Soctal Fonces 72 (1960) (discounters are innovators that provide "competition that matters"); McNair, Significant Trends and Developments in the Postwar Period, in Competitrve Distrubutron IN a Free High-Lever ECONOMY AND ITS IMPLLCATIONS FOR THE UNRVERSTTY 17, 18 (A. Smith ed. 1958) (explanation of the classic "wheel of retail" theory-innovation brought to retailing by discounters and others meets needs unfulfilled by established retailers; successful innovators become established retailers, and process begins anew).

10448 F. Supp. at 1334.

20 Cernuto, Inc. v. United Cabinet Corp., 595 F.2d 164, 166 (3d Cir. 1979).

21 Id. 166.

22448 F. Supp. at 1337.

23 Id. 1335-36. 
spired to protect Famous from price competition by Cernuto, and that United and Lappin terminated Cernuto at Famous' request and in pursuit of a price related end, then it can prevail on a price-fixing theory notwithstanding its failure to show any impact on competition involving kitchen cabinet sales in Western Pennsylvania. ${ }^{24}$

At trial, defendants could escape application of a per se rule by demonstrating either that United's decision was in fact its own, and therefore essentially unilateral and vertical, or that their actions were not motivated solely by price considerations. Alternatively, they could escape section 1 of the Sherman Act altogether if Cernuto failed to prove the existence of concerted action.

The relationship in Cernuto between a distributor and a manufacturer is vertical in nature, and under Sylvania the general standard for judging such arrangements is the rule of reason. ${ }^{25}$ Sylvania itself, however, suggested certain exceptions to this rule. For example, price fixing and resale-price maintenance, even if vertical in form, remain illegal per se. ${ }^{26}$ Thus, Judge Adams could have invoked the per se rule on this theory alone. ${ }^{27}$ Instead, he approached the restraint first in terms of its horizontal impact.. ${ }^{28}$ By so doing, he distinguished Sylvania, not only on the ground that Sylvania involved only a nonprice vertical restraint, but also on the difference in the purposes underlying the restraints in the two cases. Judge Adams interpreted Sylvania to mandate a rule of reason only for

24 Cernuto, Inc. v. United Cabinet Corp., 595 F.2d 164, 170 (3d Cir. 1979).

25 Continental T.V., Inc. v. GTE Sylvania Inc., 433 U.S. 36, 59 (1977).

26 Id. 51 n.18. See United States v. General Motors Corp., 384 U.S. 127 (1966) (vertical price fixing illegal per se); Dr. Miles Medical Co. v. John D. Parks \& Sons Co., 220 U.S. 373 (1911) (resale-price maintenance). But see Eastern Scientific Co. v. Wild Heerbrugg Instruments, Inc., 572 F.2d 883 (Ist Cir.), cert. denied, 439 U.S. 833 (1978) (resale-price maintenance judged by rule of reason); The Future of the Per Se Rule, supra note 7 (Sylvania may provide rationale for not applying per se rule to vertical price fixing).

27 See, e.g., United States v. General Motors Corp., 384 U.S. 127 (1966) (elimination of discounters to eliminate prices illegal per se); United States v. Parke, Davis \& Co., 362 U.S. 29 (1960) (resale-price maintenance illegal per se); United States v. Socony-Vacuum Oil Co., 310 U.S. 150 (1940) (characterization of conduct as price fixing and therefore illegal per se).

28 Cernuto, Inc. v. United Cabinet Corp., 595 F.2d 164, 167 n.15 (3d Cir. 1979) ("[A]lthough we are confronted here with an apparently vertical conspiracy, the principal impact of that conspiracy ... is horizontal rather than vertical in nature."). Judge Adams also found support for application of a per se rule in the alleged object of the conspiracy, elimination of the discounter's price competition. Id. 169. He hinted, however, that horizontal impact alone might be sufficient to invoke the per se rule when, in discussing two nonprice cases, he suggested the Third Circuit might there have accepted per se theories rejected by other circuits. Id. That price fixing constitutes a per se violation, whether the restraint is vertical or horizontal, is widely accepted. See note 26 supra \& accompanying text. 
restraints imposed unilaterally by a manufacturer on intrabrand competition. ${ }^{29}$ When the restraint, albeit vertical in form, resulted in fact from pressure by a distributor upon a manufacturer, "the desired impact is horizontal and on the dealer, not the manufacturer, level." 30 Such restraints with horizontal purposes fall outside Sylvania's scope and may be subject to a per se rule. ${ }^{31}$

This Comment will now turn to a more detailed and critical consideration of Judge Adams's treatment of Sylvania. Second, the Comment will examine the theory and significance of characterizing vertical arrangements as horizontal because of their horizontal purpose and effect. The Comment will then confront what appears to be a contrary approach in the Second Circuit ${ }^{32}$ and, finally, will explore the practical difficulties in applying Cernuto.

\section{Sylvania, Unilateral Decisions, and Vertical Restraints}

In Sylvania, ${ }^{33}$ GTE Sylvania, a manufacturer of televisions, terminated the distributorship of Continental T.V., a television retailer, after the latter had violated Sylvania's restrictions on distribution locations. Sylvania had imposed these restrictions as part of its marketing strategy to reverse declining sales and to improve its competitive stance in the television manufacturing industry. ${ }^{34}$ Continental argued that Sylvania's territorial restrictions were per se illegal under the rule of United States v. Arnold, Schwinn of Co.35 The Court overturned Schwinn, rejected Continental's argument, and ruled that nonprice vertical restraints challenged under section 1 of the Sherman Act ${ }^{36}$ were to be judged by the rule of reason. ${ }^{37}$

In Cernuto Judge Adams reasoned that, unlike the restraint in Sylvania, the restraint in Cernuto was not "unilateral": "When a marketing decision, although ostensibly taken by a manufacturer, is in fact the result of pressure from another customer, such a deci-

$29595 \mathrm{~F} .2 \mathrm{~d}$ at 167.

30 Id. 168.

$31 \mathrm{Id}$.

32 See Oreck Corp. v. Whirlpool Corp., 579 F.2d 126 (2d Cir.) (en banc), cert. denied, 439 U.S. 946 (1978).

33 Continental T.V., Inc. v. GTE Sylvania Inc., 433 U.S. 36 (1977).

34 Id. 37-39.

35388 U.S. 365 (1967). "Under the Sherman Act, it is unreasonable without more for a manufacturer to seek to restrict and confine areas or persons with whom an article may be traded after the manufacturer has parted with dominion over it." Id. 379 .

3615 U.S.C. $\$ 1$ (1976). See note 10 supra.

37 Continental T.V., Inc. v. GTE Sylvania Inc., 433 U.S. 36, 58-59 (1977). 
sion must be scrutinized more closely than solely unilateral action might be." 38 His distinction is based on "the law's traditional tolerance of unilateral decisions on the part of a manufacturer," ${ }^{39}$ which can be traced to the manufacturer's right, articulated in United States $v$. Colgate of Co.,40 "freely to exercise his own independent discretion as to parties with whom he will deal." 41 Theoretically, a manufacturer acting unilaterally may pursue certain goals, such as resale-price maintenance, that would be illegal per se if not unilateral acts. ${ }^{42}$ A manufacturer's reliance on the Colgate doctrine, however, is limited to "mere announcement of his policy and the simple refusal to deal." 43 Once the manufacturer's refusal to deal is tainted by duality of action, as manifested by the existence of an agreement, whether express or implied, ${ }^{44}$ the doctrine is not applicable. ${ }^{45}$

At first blush, distinguishing Sylvania on the onesidedness of the action appears unpersuasive. Vertical restraints are usually spelled out in a dealer's contract ${ }^{46}$ and thus necessarily involve agreement between manufacturers and distributors. In a sense, therefore, all vertical restrictions, at least when there has been some

38 Cernuto, Inc. v. United Cabinet Corp., 595 F.2d 164, 168 (3d Cir. 1979).

39 Id. 167.

40250 U.S. 300 (1919).

41 Id. 307. The principle's roots can be traced even further to the common law freedom of a trader to choose to whom he will sell. See 1 M. HANDLER, Twenty-Five Years of Antrinust 363 (1973). This freedom is reflected also in the limitation of section 1 of the Sherman Act to actions by more than one party. 15 U.S.C. $\$ 1$ (1976). See note 10 supra.

42 See United States v. General Motors Corp., 384 U.S. 127, 148 (1966) (Harlan, J., concurring). According to one court, however, the Colgate doctrine is but "a narrow channel through which a manufacturer may pass even though the facts would have to be of such Doric simplicity as to be somewhat rare in this day of complex business enterprise." George W. Warner \& Co. v. Black \& Decker Mfg. Co., 277 F.2d 787, 790 (2d Cir. 1960). See Comment, An Examination of Doric Simplicity: The Criteria of the Decision to Cease Business Relations, 10 Vir. L. REv. 117 (1964).

43 United States v. Parke, Davis \& Co., 362 U.S. 29, 44 (1960).

44 FTC v. Beech-Nut Packing Co., 257 U.S. 44I, 453 (1922). See Turner, The Definition of Agreement Under the Sherman Act: Conscious Parallelism and Refusals to Deal, 75 Harv. L. Rev. 655, 655-56 (1962).

45 See United States v. Parke, Davis \& Co., 362 U.S. 29 (1960) (illegal agreement to maintain resale prices); Klor's, Inc. v. Broadway-Hale Stores, Inc., 359 U.S. 207 (1959) (illegal concerted refusal to deal); Associated Press v. United States, 326 U.S. 1 (1945) (illegal exclusive arrangement); United States v. Bausch \& Lomb Optical Co., 321 U.S. 707 (1944) (illegal resale-price maintenance); FTC v. Beech-Nut Packing Co., 257 U.S. 441 (1922) (illegal resale-price maintenance); United States v. A. Schrader's Son, 252 U.S. 85 (1920) (illegal resale-price maintenance).

46 A common example of restriction by contract is the franchise agreement. Vertical Restrictrons, supra note 6 , at 1 . 
negotiation between the parties, are non-unilateral and cannot be excused under the Colgate doctrine.

Judge Adams's approach is more plausible, though, if analysis is focused on the decision to impose a restraint, rather than on the agreement by which the restraint is imposed. A restraint is unilateral if it represents the manufacturer's independent decision to control its distributors in its own interest. Restraints imposed by the manufacturer as a result of capitulation to dealer or other outside pressure are non-unilateral. The Cernuto approach implies that only those restraints imposed unilaterally by a manufacturer, that is, as a result of a manufacturer's decision alone, are "vertical restraints."

This definition of vertical restraint is not inconsistent with Sylvania or with the case law in other circuits. In Sylvania, the business arrangement found to be a vertical restriction was a location restraint imposed unilaterally by GTE as part of its marketing strategy. No evidence suggested dealer pressure.47 When restraints have been imposed by a manufacturer or supplier on its own initiative-unilaterally-other courts have likewise accepted the restraint as vertical. ${ }^{48}$ But in cases in which the restraint, although vertical in form, was imposed non-unilaterally, the restraint has been considered horizontal. ${ }^{49}$ In United States $v$. Sealy, Inc.. ${ }^{50}$ for instance, the Court treated a territorial restriction imposed by a trademark licensor as a horizontal restraint. Sealy was in the business of licensing manufacturers to produce and sell Sealy brand-name mattresses. In fact, however, Sealy was a joint venture of these very

47 Continental T.V., Inc. v. GTE Sylvania Inc., 433 U.S. 36, 38-39 (1977).

48 See, e.g., United States v. Arnold, Schwinn \& Co., 388 U.S. 365, 372-73 (1967), overruled on other grounds, Continental T.V., Inc. v. GTE Sylvania Inc., 433 U.S. 36 (1977); White Motor Co. v. United States, 372 U.S. 253 (1963) (vertical restrictions imposed solely by manufacturer); In re Nissan Antitust Litigation, 577 F.2d 910, 915 (5th Cir. 1978) (vertical restrictions are limitations imposed by manufacturer); H \& B Equip. Co. v. International Harvester Co., 577 F.2d 239, 245-46 (5th Cir. 1978) (vertical restraints originate with manufacturer); Munters Corp. v. Burgess Indus. Inc., 450 F. Supp. 1195, 1208 (S.D.N.Y. I977) (impetus for vertical restriction must come from manufacturer); Evanston Motor Co. v. Mid-Southern Toyota Distribs., Inc., 436 F. Supp. 1370, 1372 (N.D. Ill. 1977) (pure vertical restraint). Cf. Oreck Corp. v. Whirlpool Corp., 579 F.2d 126, 131 (2d Cir.) (en banc), cert. denied, 439 U.S. 946 (1978) ("vertical' restraints, i.e. combinations of persons at different levels of the market structure") (emphasis added). See also R. Bork, The Antrtrust Paradox 288 (1978).

49 See, e.g., United States v. Topco Assocs., 405 U.S. 596 (1972) (cooperative association of supermarket chains allocating territories and limiting resale); United States v. Sealy, Inc., 388 U.S. 350 (1967) (joint venture allocating territories among members and fixing prices); United States v. General Motors Corp., 384 U.S. 127 (1966) (manufacturer and dealers cooperating to secure and enforce restraints on dealers).

50388 U.S. 350 (1967). 
licensees, ${ }^{51}$ which constituted Sealy's board of directors, the body that had imposed the restriction. Finding that the restraints were the creature of the licensees, rather than of Sealy, the Court held the restraint horizontal.62

The result in Sealy does not mandate the conclusion in Cernuto. Sealy involved several manufacturer-licensees acting, through the licensor they controlled, to restrain licensees. The conspiracy, among parties at the same level, was directed at parties also at that level-a typical horizontal scheme except for the involvement of the licensor as the "instrumentality of the licensees." 53 In Cernuto, on the other hand, only one alleged conspirator was on the same level with the damaged retailer. Arguably, therefore, the conspiracy was not at one level, and the restraint should not be classed as horizontal. ${ }^{54}$ This distinction does not make sense: as long as the impetus for a restraint comes from a competitor, a party at the same level as the object of that restraint, it should be treated as horizontal, whether the conspiracy is at that level, that is, among competitors, or is between levels, for instance, involving a manufacturer and a retailer.

The argument that a restraint prescribed by a competitor takes on a horizontal character and is not given the latitude accorded vertical restraints was accepted by the Eighth Circuit in Quality Mercury, Inc. v. Ford Motor Co.55 In that case, Ford had bound itself not to create another Lincoln automobile dealership in the Minneapolis area without the consent of Prestige Lincoln-Mercury, one of its dealers. Quality, which had been operating a Mercury dealership in the area, alleged that its attempt to secure a Lincoln dealership was blocked by Prestige under the Ford-Prestige agreement. The court read Quality's section 1 complaint to allege "an arrangement whereby a horizontal competitor . . . has a perpetual veto power over all applications for Lincoln franchises in the Min-

51 Id. 353. The licensees owned substantially all of the Sealy stock. Id. 352. 52 Id. 354.

53 Id.

54 For a more extensive discussion of this argument, see notes 102-23 infra \& accompanying text.

55542 F.2d 466 (8th Cir. 1976), cert. denied, 433 U.S. 914 (1977). See Oreck Corp. v. Whirlpool Corp., 563 F.2d 54, 65 (2d Cir. 1977) (Mansfield, J., dissenting) (applying Quality Mercury to case of dealer termination), aff'd en banc, 579 F.2d 126 (2d Cir.), cert. denied, 439 U.S. 946 (1978); American Motor Inns, Inc. v. Holiday Inns, Inc., 521 F.2d 1230 (3d Cir. 1975) (Adams, J.) (franchisee veto power over grant of new franchises). Cf. Ethyl Gasoline Corp. v. United States, 309 U.S. 436 (1940) (licensing conditions for patented process not justified by patent monopoly when used for commercial development of licensees). 
neapolis area." 56 So construed, the court found that Quality's complaint stated a proper claim for relief under the antitrust laws and reversed the district court's dismissal on the pleadings.

The facts in Quality Mercury are analogous to those alleged in Cernuto. In each, the violation charged was a manufacturer's refusal to deal with a distributor, in form, at least, a vertical restraint. In addition, however, a competitor was claimed to have instigated the restraint in both cases. The court in Quality Mercury found the alleged agreement between Ford and Prestige objectionable because the contract granted "sole discretion to a horizontal competitor as to the entry of another dealership in the Minneapolis area." 57 Although vertical in appearance, the restriction was used primarily to stifle competition on the distributor level, and ultimate power was in the hands of the distributor. A restraint caused by such an arrangement, the court held, may be unreasonably anticompetitive and therefore may constitute a violation of the Sherman Act. ${ }^{58}$

Although the court stated that anticompetitive effect was the justification for the outcome of the case, ${ }^{59}$ impact should not be determinative. ${ }^{60}$ The Supreme Court has adjured courts to avoid "formalistic line drawing," ${ }^{11}$ and the immediate effect of excluding competitors is the same whether resulting from a unilateral decision by a manufacturer or from a veto by a competitor. Preferable is a distinction according to purpose. Valid, procompetitive reasons may justify a manufacturer's unilateral decision, despite some anticompetitive effects, but when a competitor is the source of the restraint, the purpose itself, which is directed horizontally, is likely to be anticompetitive. At the least, Quality Mercury, like Sealy, suggests that vertical form will not insulate a restraint with horizontal purpose from scrutiny greater than that given unilateral

56 Quality Mercury, Inc. v. Ford Motor Co., 542 F.2d 466, 468 (8th Cir. 1976), cert. denied, 433 U.S. 914 (1977).

57 Id. 471 (emphasis in original).

$58 \mathrm{Id}$. 471 \& 471-72 n.6. Quality Mercury did not assert a per se violation, id. $469 \mathrm{n.2}$; the court, in reversing the dismissal, found that the plaintiffs had alleged a restraint unlawful under a rule of reason.

Quality Mercury was decided before the Court's decision in Continental T.V., Inc. v. GTE Sylvania Inc., 433 U.S. 36 (1977), but that distinction does not affect this Comment's analysis of the case.

50542 F.2d at $471 \& 471-72$ n.6.

$60 \mathrm{~L}$. Sulurvan, supra note 8 , at 195 . See United States v. Socony-Vacuum Oil Co., 310 U.S. 150, 224 n.59 (1940). Although impact should not be controlling, anticompetitive effects may be relevant and may be inferred from anticompetitive purposes: "purpose . . . can stand as a surrogate for effects." L. SullivaN, supra note 8 , at 195 .

61 Continental T.V., Inc. v. GTE Sylvania Inc., 433 U.S. 36, 59 (1977). 
vertical restraints. Moreover, it presages the reasoning in Cernuto that a restriction with a horizontal purpose, though a vertical form, should be treated as a horizontal restraint. The relevant purpose is presumed to be that of the party prescribing the restraint. The following section explores the relationship between a restraint's origin and its likely purpose.

\section{Distribution Cfannnels: Posttion as a Guide to Purpose}

The Supreme Court's decision in Sylvania relied on the premise that restraints imposed by a manufacturer on intrabrand competition may enhance interbrand competition by permitting the manufacturer to realize certain marketing efficiencies. ${ }^{62}$ These efficiencies are achieved by the construction and exploitation of what are known as marketing or distribution channels. ${ }^{63}$ Distribution channels have been variously described, ${ }^{64}$ but are essentially the means by which the manufacturer gets its product, in the desired form, to the consumer. ${ }^{65}$ A distribution channel is intended to enhance the competitive position of the manufacturer's product relative to the products of other manufacturers. ${ }^{86}$

Much conflict can exist within a distribution channel. ${ }^{67}$ One source of conflict is vertical, ${ }^{68}$ conflict between the manufacturer's "universal" goals-the improvement of its product's competitiveness

62 Id. 54-55.

63 See, e.g., P. Converse, H. Huegy, \& R. Mrtchell, Elements of Marketing 531-52 (7th ed. 1965); J. HESKETT, MARKETING 257-364 (1976); E. MCCARTHX, Bastc Marketing: A Managerial Approach 300-85 (5th ed. 1975).

64 See Davidson, Channels of Distribution-One Aspect of Marketing Strategy, Business Honzons, Feb., 1961, at 84, reprinted in L. Boone \& J. Jornson, Marketing Channels 3 (1973).

65 The choice of a particular channel is a strategic decision based upon consideration of, inter alia, the marketing objective, the market environment, and the manufacturer's resource pool. See M. Bell, Marketrang Concepts \& Strategy 455-92 (1966).

60 The following discussion does not necessarily pertain to distributors, such as wholesalers and jobbers, other than retailers in general. To the extent, however, that they share the characteristics of retailers in general, the following discussion is relevant in assessing their role in a distribution channel. The following discussion also omits consideration of "dual distribution systems," in which vertically integrated manufacturers function at the same level of distribution as their distributors. Manufacturer involvement in distribution may transform otherwise vertical restraints into horizontal restraints. See Vertical Restrictions, supra note 6, at 2 n. 3 (listing cases).

67 See W. Alderson, Dynamtc Marketing Behayior 239 (1965); Mallen, Conflict and Cooperation in Marketing Channels, in The Marketing Channel 124 (B. Mallen ed. 1967); Stern \& Gorman, Conflict in Distribution Channels: An Exploration, in L. Stern, Distrubution Channels: Behavioral Dimensions 156 (1969).

88 See R. Patamountain, The Politics of Distrimution 48 (1955). 
-and the subgoals of such distributors as retailers-pursuit of their own conceptions of profit maximization or assertion of their independence. ${ }^{69}$ Retailers tend to consider themselves as independent businessmen, rather than as mere agents distributing a manufacturer's product. ${ }^{70}$ Most retailers carry a large number of items but only a relatively small inventory of any single item or product line. ${ }^{71}$ A retailer's efforts are directed primarily toward obtaining orders for all of its products rather than for any single item. ${ }^{72}$ The simultaneous representation of various manufacturers in the same store inherently reinforces the retailer's conception of itself as an independent business. Due to the nature of its business, the retailer's interests may even be adverse to those of the manufacturer. ${ }^{73}$

Vertical restraints, such as territorial restrictions, are designed to control this vertical conflict, ${ }^{74}$ but they also control horizontal conflict within the channel. ${ }^{75}$ Horizontal conflict arises between components operating on the same level of distribution and pursuing separate, independent subgoals. ${ }^{76}$ Among retailers, horizontal conflict may assume the proportions of rivalry.

69 The model is borrowed from Williamson, supra note 5, at 955-56 \& n.13.

70 See Wittreich, Misunderstanding the Retailer, Harv. Bus. REv., May-June, 1962 , at 147.

71 See E. McCARthy, supra note 63, at 325.

72 See McVey, Are Channels of Distribution What the Textbooks Say?, J. Marketing, Jan., 1960, at 61, 64.

73 Consider, for example, a territorial restriction imposed by a manufacturer to induce dealer services. Prior to the restraint the favored dealer faced intrabrand competition. Afterwards, however, it has profits that would have been precluded by intrabrand competition. (Pricing discretion is still constrained by interbrand competition.) The dealer now has funds to invest in presale, point-of-sale, or postsale services, for example, (1) services to differentiate the manufacturer's product; (2) services such as a redecorated showroom to differentiate the dealer's store and indirectly all products sold therein; or (3) services to differentiate the products of other manufacturers. The dealer will invest the funds in the option providing the greatest returns. That choice may not necessarily be the first option, which would increase sales of the manufacturer's product. If the manufacturer is concerned only with increasing output, option (2) may satisfactorily dovetail with this goal. But if the manufacturer's goal is to increase its market share, that choice will not serve its interests unless the dealer does not carry products of competing manufacturers.

Cf. Fuchs Sugars \& Syrups, Inc. v. Amstar Corp., 602 F.2d 1025, 1028-29 (2d Cir.), cert. denied, $100 \mathrm{~S}$. Ct. 232 (1979) (customer orientation of sugar brokers).

$\mathbf{7 4}$ "[V]ertical territorial restraints may be used to increase perception of mutual self-interest and to restrain conduct not in accord with it." Strasser, Vertical Territorial Restraints After Sylvania: A Policy Analysis and Proposed New Rule, 1977 DUKE L.J. 775, 787.

75 See Verticat Restructions, supta note 6, at 4-5.

76 See R. Palamountati, supra note 68, at 24. 
Rivalry among retailers is not waged primarily on an intrabrand or interbrand basis, but generally on an interstore basis. The product is the store. Retailers compete as units composed of bundles of goods and services in exploiting an appealing image or a strategic geographical location. It's Macy's against Gimbel's, with everything thrown into the fray, from consumer credit to plentiful parking spaces to smartly dressed salespeople. ${ }^{77}$ An important weapon in interstore rivalry is inventory, a broad, perhaps even redundant, offering of products and styles. ${ }^{78}$ A diverse inventory is particularly invaluable in an industry in which the crucial objective is to bring the shopper in off the street so that he may be exposed to the store's full range of offerings. By inducing a manufacturer to refuse to deal, a retailer can strike a serious, if not irreparable, blow against a rival.

Because a manufacturer's goals are aimed at increasing interbrand competition, that is, competition among manufacturers, the purpose of a restraint on a distribution channel imposed unilaterally by a manufacturer may be presumed to be procompetitive. As the Court noted in Sylvania, vertical restraints may reduce intrabrand competition, but they are most often intended to improve the manufacturer's market position relative to that of competing manufacturers. ${ }^{79}$ A manufacturer can only rarely abuse its ability to restrain intrabrand competition to realize objectives in the inter-

77 See J. Heskett, supra note 63, at 271-73, 279-80; P. McAnaldy, The Economics of the Distributtue Trade (1971); E. McCarthy, supra note 63, at 319-20; Lozer \& Kelley, The Retailing Mix: Planning and Management, J. RETAILING, Spring, 1961, at 34; Martineau, The Personality of the Retail Store, Harv. Bus. REv., Jan.-Feb., 1958, at 47.

"The real or imagined differences that set products apart may be due to the firm's reputation, its congenial and courteous sales personnel, an attractive brand name, an appealing package or a convenient location." W. Davisson \& J. RANLETT, AN INTRODuction to Microeconomic Theory 192-93 (1965), quoted in Mueller, Antitrust \& Economics: A Look at "Competition," 10 ST. Lous U.L.J. 482, 494 n.59 (1966).

78 Most [retailers] regard their stock as the foundation of their business. In Daniel DeFoe's language: "'tis the having a shop well filled with goods, having good choice to sell, and selling reasonable, these are the things that bring a trade, and the trade thus brought will stand by you, and last."

P. McNaLxy, supra note 77 , at 58 .

${ }^{79}$ Continental T.V., Inc. v. GTE Sylvania Inc., 433 U.S. 36, 57-58 (1977). In fact, a distribution channel responsive to the manufacturer's interbrand strategy may be viewed as a single economic unit, a distributive system competing with the distributive systems of other manufacturers. See McCammon \& Bates, The Emergence and Growth of Contractually Integrated Channels in the American Economy, in The Marketrng Channel 287 (B. Mallen ed. 1967). Seen in this light, vertical restraints imposed on a distribution channel by a manufacturer involve only one economic unit and perhaps may be said to fall outside the purview of $\S 1$ of the Sherman Act. 
brand market: 80 " $[\mathrm{t}]$ he degree of intrabrand competition is wholly independent of the level of interbrand competition confronting the manufacturer. ... [W] [Wen interbrand competition exists . . . it provides a significant check on the exploitation of intrabrand market power because of the ability of consumers to substitute a different brand of the same product." 81 The reasonableness of vertical restraints imposed unilaterally by manufacturers may therefore be judged by balancing the procompetitive (interbrand) effects against those that are anticompetitive (intrabrand). ${ }^{82}$

Distributors' goals likewise relate to competition at the level at which they operate-competition with each other. Horizontal restraints are "naked restraints of trade with no purpose except stifling of competition" 83 and will generally be subject to a per se rule. $^{84}$ A supplier's involvement in a horizontal restraint does not negate this presumption by adding a procompetitive intent. The supplier participates merely as the "enforcement agent" 85 in furthering the distributors' anticompetitive and horizontal purposes. A refusal to deal, taken at the direction of a distributor, can have the purpose and effect of reducing or eliminating intrabrand and interstore competition without the countervailing benefit, presumed to result from unilateral action by the manufacturer, of enhancing interbrand competition. In Mannington Mills, Inc. v. Congoleum Industries, Inc., ${ }^{86}$ the Third Circuit explained, "[a]s we pointed out in Cernuto, dealer inspired terminations may pose serious anticompetitive risks not presented by a manufacturer's unilateral refusal to deal." 87

80 See R. Bork, supra note 48, at 297: "Basic economic theory tells us that the manufacturer who imposes such restraints cannot intend to restrict output and must . . . intend to create efficiency."

81 Continental T.V., Inc. v. GTE Sylvania Inc., 433 U.S. 36, 52 n.19 (1977).

82 Compare United States v. Topco Assocs., 405 U.S. 596 (1972) (horizontal restraint) and United States v. Sealy, Inc., 388 U.S. 350 (1967) (horizontal restraint) with Continental T.V., Inc. v. GTE Sylvania Inc., 433 U.S. 36 (1977) (vertical restraint) and United States v. Sealy, Inc., 388 U.S. 350, 358-64 (1967) (Harlan, J., dissenting). See also Gough v. Rossmoor Corp., 585 F.2d 381, 38689 (9th Cir. 1978), cert. denied, 440 U.S. 936 (1979) (rule of reason balances the competitive and anticompetitive benefits of restraint); Pitofsky, supra note 18; Comment, A Proposed Rule of Reason Analysis for Restrictions on Distribution, 47 FordhaM L. REv. 527 (1979).

83 White Motor Co. v. United States, 372 U.S. 253, 263 (1963).

84 New entrants and weak firms may be candidates for exceptions to this general rule. See Brown Shoe Co. v. United States, 370 U.S. 294, 319, 331 (1962) (exceptions to per se rules recognized for small companies attempting to compete with larger companies and for failing companies attempting to remain in business).

85 Posner, The Rule of Reason and the Economic Approach: Reflections on the Sylvania Decision, 45 U. CHI. L. Rev. 1, 17 (1977).

86 [1979-2] Trade Cas. \62,790 (3d Cir. 1979).

87 Id. 78,582 . 
Applying a vertical analysis to such restraints would produce distorting results. ${ }^{88}$ Vertical analysis would permit defendants to concoct as a defense allegedly offsetting interbrand competitive effects. But these are essentially unintended effects. Efficiency, even if it could be shown to result from a dealer-prescribed restraint, should not impede justice. ${ }^{89}$ Furthermore, vigorous interbrand competition will not likely be able to buffer diminished interstore competition, especially when competing products are sold side by side in the same store.

In light of these realities, a court, faced with a restraint ostensibly imposed by a manufacturer but in fact dictated by a distributor, should apply a horizontal analysis. The affected competition, interdealer and interstore competition, can then be the gauge for judging the restraint. Once vertical analysis is deemed inappropriate, the presumption of offsetting procompetitive effects disappears, and the court's inquiry is limited to the anticompetitive effects in the restrained market. ${ }^{90}$ Arrangements, such as territorial division, that would be tested under a rule of reason if analyzed as a vertical restraint may therefore be subject to a per se rule when their only vertical characteristic is their form.

\section{A Gloss on Substance: Oreck Corp. v. Whirlpool Corp.}

Cernuto advances an approach at odds with that taken by the Second Circuit in Oreck Corp. v. Whirlpool Corp. ${ }^{\text {a1 }}$ Judge Adams distinguished Oreck on its facts, ${ }^{92}$ but the rift between the circuits

88 For discussion of a case applying vertical analysis to a dealer-prescribed termination, see notes 91-137 infra \& accompanying text.

89 Amidst the raging controversy about the goals of the antitrust laws, compare R. Bork, supra note 48, at 50-89; R. PosNER, supra note 7, at 8-22 and Elzinga, The Goals of Antitrust: Other Than Competition and Efficiency, What Else Counts?, 125 U. PA. L. Rev. 1191 (1977) with Bohling, supra note 5; Pitofsky, The Political Content of Antitrust, 127 U. PA. L. Rev. 1051 (1979) and Schwartz, "Justice" and Other Non-Economic Goals of Antitrust, 127 U. PA. L. REv. 1076 (1979), at least one safe proposition is that neither justice, social goals, nor economic or judicial efficiency is well-served by post hoc rationalizations for objectionable behavior. See also note 60 supra \& accompanying text.

90 See United States v. Topco Assocs., 405 U.S. 596, 609-12 (1972) (judicial scrutiny confined to restrained portion of economy); Schwartz, supra note 89, at 1080 ("[W]hen 'effect on competition" is the criterion of legality, an adverse effect in one market should suffice to condemn the transaction without exploring the possible pro-competitive impact in another market.") (footnote omitted).

91579 F.2d 126 (2d Cir.) (en banc), cert. denied, 439 U.S. 946 (1978). See also Comment, Vertical Agreements to Terminate Competing Distributors: Oreck Corp. v. Whirlpool Corp., 92 HARv. L. REv. 1160 (1979) (applauding Oreck).

92 Cernuto, Inc. v. United Cabinet Corp., 595 F.2d 164, 169-70 (3d Cir. 1979). Judge Adams also distinguished on its facts Packard Motor Car Co. v. Webster Motor Car Co., 243 F.2d 418 (D.C. Cir.), cert. denied, 355 U.S. 822 (1957). 
may not be so readily explained. As Judge Adams admitted, "we are not convinced that this Court would necessarily have decided ... Oreck the same way had we been presented with the identical factual configuration." 93

In Oreck, a distributor, Oreck, sued its supplier, Whirlpool, and a competing distributor, Sears Roebuck \& Co., because of alleged violations of section 1 of the Sherman Act. Whirlpool is a manufacturer of, among other things, vacuum cleaners. Most of its business was with Sears, which sold Whirlpool vacuum cleaners under the "Kenmore" label.94 In 1963, Whirlpool entered into an agreement with Oreck making it the exclusive distributor of "Whirlpool" brand vacuum cleaners for a five-year period. The agreement was extended after five years for another three. At the end of this period, Whirlpool informed Oreck that it intended to allow the sales agreement to expire and thereby to terminate Oreck's exclusive distributorship.

Oreck claimed that Whirlpool's action came at the "behest and insistence" of Sears ${ }^{95}$ and that the agreement between Sears and Whirlpool constituted a group boycott subject to a per se rule.96 The trial court accepted this argument and instructed the jury accordingly, but the court of appeals reversed, ruling that the conduct was to be analyzed under a rule of reason. ${ }^{97}$

Packard is also distinguishable as a case relying on the failing-firm doctrine. See note 134 infra.

93 Cernuto, Inc. v. United Cabinet Corp., 595 F.2d 164, 169 (3d Cir. 1979).

94 Since 1925 Sears has been the principal distributor of Whirlpool products, currently purchasing more than two-thirds of Whirlpool's total appliance production and, at the time of the events here involved, more than $90 \%$ of Whirlpool's vacuum cleaner output for resale under Sears' "Kenmore" label. In addition Sears, beginning in 1925, purchased a substantial block of Whirlpool's common stock and by 1960 became its largest single stockholder, owning 251,192 shares and usually electing one or more of its executives to Whirlpool's board of directors.

Oreck Corp. v. Whirlpool Corp., 579 F.2d 126, 135 (2d Cir.) (en banc) (Mansfield, J., dissenting), cert. denied, 439 U.S. 946 (1978). See Wall St. J., Aug. 19, 1968, at 1 , col. 1 (describing Whirlpool as a "captive company" of Sears).

85579 F.2d at 128.

96 Id. 131. Oreck also alleged that Whirlpool and Sears were motivated by price considerations. This argument, however, was raised only on appeal and was therefore dismissed. Id. 130-31.

97 Id. 134. Judge Mansfield, joined by Judge Feinberg, issued a ringing dissent. According to Judge Mansfield, if Sears and Whirlpool agreed to cut off supplies to Oreck, the combination was "sufficiently pernicious in its purpose and effect to be unreasonable, per se, and hence illegal." Id. 138 (Mansfield, J., dissenting). Secondly, although a manufacturer may act on its own to substitute one exclusive distributor for another, when it "agrees with one or more existing competitors of its distributor to cut off the distributor .... the resulting termination is unlawful." Id. 139 (citations omitted). Thirdly, Judge Mansfield distinguished Sylvania on the ground that Oreck involved a boycott, not a vertical restriction. Id. 140. 
Essential to the Second Circuit's holding was its finding that the challenged conduct was a vertical restraint and therefore to be judged by a rule of reason, even though the termination may have been directed by Sears. ${ }^{98}$ Three identifiable grounds premise the court's finding. First, the court defined horizontal and vertical restrictions in terms of their form, rather than their purpose or effect. ${ }^{99}$ Second, the court viewed the case as involving merely a manufacturer's attempt to grant an exclusive distributorship. ${ }^{100}$ Third, the court held that a per se rule was inappropriate for arrangements between one distributor and one dealer. ${ }^{101}$

The first and third grounds may be considered together. Both reflect an assumption that a plurality of parties on the restrained level of distribution is necessary in order to treat a vertical arrangement as a horizontal restraint. This approach was cited with approval by the Ninth Circuit in Gough $v$. Rossmoor Corp. ${ }^{102}$ There, upon somewhat analogous facts, the court ruled:

Such concert of action may suffice to create a conspiracy but it cannot suffice to constitute such a concerted refusal to deal as has so far been held to be per se unreasonable. In all cases so far holding such restraints to be per se unreasonable, there has been some horizontal concert of action taken against the victims of the restraint. ${ }^{103}$

In even starker terms, in $H$ \& $B$ Equipment Co. v. International Harvester Co., ${ }^{104}$ the Fifth Circuit wrote, "[c]onspiracies between a manufacturer and its distributors are only treated as horizontal, however, when the source of the conspiracy is a combination of the distributors." 105

As support for this proposition, the subscribing courts have invariably cited ${ }^{106}$ the Supreme Court's opinion in either United

98579 F.2d at 131.

99 "It is important to distinguish between 'horizontal" restraints, i.e. agreements between competitors at the same level of market structure, and 'vertical' restraints, i.e. combinations of persons at different levels of the market structure, such as manufacturers and distributors." Id. (citation omitted).

100 Id. 13I-32 n.6.

$101 \mathrm{Id}$.

102585 F.2d 381 (9th Cir. 1978), cert. denied, 440 U.S. 936 (1979).

103 Id. 387.

104577 F.2d 239 (5th Cir. 1978).

105 Id. 245 (citations omitted).

106 See Gough v. Rossmoor Corp., 585 F.2d 381, 387 n.7 (9th Cir. 1978), cert. denied, 440 U.S. 936 (1979); Oreck Corp. v. Whirlpool Corp., 579 F.2d 126, 13133 (2d Cir.) (en banc), cert. denied, 439 U.S. 946 (1978); H \& B Equip. Co. v. International Harvester Co., 577 F.2d 239, 245 (5th Cir. 1978). 
States v. General Motors Corp. ${ }^{107}$ or Klor's, Inc. v. Broadway-Hale Stores, Inc. ${ }^{108}$ In the former the Court found that an agreement between General Motors and its distributors to refuse to deal with discount sellers of new Chevrolets was illegal per se for two reasons. The first was that a purpose of the boycott was to protect the favored dealers from price competition by destroying the discounters. ${ }^{109}$ The other ground was the boycott itself, which the Court termed "a classic conspiracy in restraint of trade: joint, collaborative action by dealers, the appellee associations, and General Motors to eliminate a class of competitors by terminating business dealings [with] them." 110 Although a horizontal plurality did exist in General Motors, the Court nowhere relied on that factor in finding the conduct illegal.

Klor's furnishes even less support for a horizontal-plurality requirement. There, the Court held per se illegal a boycott by a large retailer, Broadway-Hale, and manufacturers of well-known brands of appliances and audio-visual equipment. The combination, designed to eliminate a small retailer, Klor's, as a competitor of Broadway-Hale, was condemned under sections 1 and 2 of the Sherman Act. ${ }^{111}$ The Court's concern was not competition on the manufacturer level, where the plurality existed, but competition on the dealer level, where no plurality existed. ${ }^{112}$ Klor's therefore may not be read to support the proposition that a plurality of parties on the restrained level is a prerequisite to applying horizontal analysis to a vertical agreement. The Supreme Court did not clearly address the horizontal-plurality requirement in either General Motors or in Klor's. ${ }^{113}$

107384 U.S. 127 (1966).

108359 U.S. 207 (1959).

109 United States v. General Motors Corp., 384 U.S. 127, 147 (1966).

110 Id. 140.

111 Klor's, Inc. v. Broadway-Hale Stores, Inc., 359 U.S. 207, $211-13$ (1959). Section 2 of the Sherman Act, in pertinent part, provides: "Every person who shall monopolize, or attempt to monopolize, or combine or conspire with any other person or persons, to monopolize any part of the trade or commerce among the several States ... shall be deemed guilty of a felony ..." 15 U.S.C. $\$ 2$ (1976).

112 "This combination takes from Klor's its freedom to buy appliances in an open competitive market and drives it out of business as a dealer in the defendants' products." Klor's, Inc. v. Broadway-Hale Stores, Inc., 359 U.S. 207, 213 (1959). See L. Sullivan, supra note 8, at 426 ("II]n Klor's the Court insisted upon placing in the foreground the horizontal characteristics and pointedly stated that the case was not one 'of a single trader refusing to deal with another, nor even of a manufacturer and dealer agreeing to an exclusive distributorship.'") (quoting Klor's, 359 U.S. at 212).

113 See Elias, Dealer Termination or Exclusion; Intrabrand Competition and GTE Sylvania, 29 BAXLoR L. REv. 435, 460-61 (1977); Bohling, Franchise Terminations Under the Sherman Act: Populism and Relational Power, 53 TEx. L. REv. 
The requirement may be attributable to an implicit assumption that only when a dealer cartel is at work may the purpose of a vertical restraint be presumed horizontal and on the dealer level.114 Vertical analysis has traditionally been considered inappropriate when a dealer cartel is involved.115 Coincidentally, in relying on the existence of such a cartel as an indication of horizontal purpose and intended effect, that well-established approach appears to be consistent with Cernuto.

This approach, however, necessarily assumes that vis-à-vis the manufacturer, an individual distributor's bargaining power is typically so inconsequential that it cannot win a concession adverse to the manufacturer's interest or one that would not have been granted otherwise. ${ }^{116}$ This assumption may be unfounded. Observers have noted a decided shift during the past several decades in bargaining power within distribution channels in favor of distributors. ${ }^{117}$ A single dealer, acting alone, may be able to place

1180,1213 (1975). For general discussions of Klor's, General Motors, and boycotts, see R. Bork, supra note 48, at 330; L. SulliviN, stpra note 8, at 229-45; Buxbaum, Boycotts and Restrictive Marketing Arrangements, 64 Micr. L. Rev. 671, 675-76 (1966); Horsley, Per Se Illegality and Concerted Refusals to Deal, 13 B.C. Indus. \& Com. L. Rev. 484 (1972); Woolley, Is a Boycott a Per Se Violation of the Antitrust Laws?, 27 Rutgers L. REv. 773 (1974).

114 Cf. H \& B Equip. Co. v. International Harvester Co., 577 F.2d 239, 245 (5th Cir. 1978) (requiring a combination of distributors before conspiracy between a manufacturer and its distributors is treated as a horizontal restraint). The court cites Posner, supra note 85 , at 17 , which condemns dealer cartels, as support for the proposition that a combination of distributors is necessary to treat a vertical arrangement as a horizontal restraint. See Bohling, supra note 5, at 505: In Sylvania "the Court stopped short of maintaining that in the absence of a horizontal dealer cartel a nonprice vertical restriction on a dealer never has the effect of restricting output. This conclusion ... rests on the assumption that a dealer's bargaining power vis a vis a manufacturer is extremely limited."

115 See Continental T.V., Inc. v. GTE Sylvania Inc., 433 U.S. 36,58 n.28 (1977) ("There may be occasional problems in differentiating vertical restrictions from horizontal restrictions originating in agreements among the retailers. There is. no doubt that restrictions in the latter category would be illegal per se . . . ."); United States v. Sealy, Inc., 388 U.S. 350 (1967); Gough v. Rossmoor Corp., 585 F.2d 381 (9th Cir. 1978), cert. denied, 440 U.S. 936 (1979); R. Bork, supra note 48 , at 288 ; L. SullivaN, supra note 8 , at 383 ; R. PosNeR, supra note 7 , at 151 n.24.

116 See Bohling, supra note 113, at 1181; Comment, Vertical Agreements to Terminate Competing Distributors: Oreck Corp. v. Whirlpool Corp., 92 Harv. L. Rev. 1160, 1165 (1979).

117 See R. Holloway \& R. Hancock, Marketing in a Changing EnvmonMENT 399 (1973); McCammon \& Bates, supra note 79, at 287; McVey, supra note 72, at 65; Strasser, supra note 74, at 789; Note, Restricted Channels of Distribution Under the Sherman Act, 75 HARv. L. Rev. 795, 805-07 (1962). But see Comment, Vertical Agreements to Terminate Competing Distributors: Oreck Corp. v. Whirlpool Corp., 92 Harv. L. REv. 1160, 1169 (1979) (concluding that manufacturers" bargaining power is generally superior to that of distributors). 
enough pressure upon a supplier to win concessions beneficial primarily to the dealer's own interests. ${ }^{118}$ Enforcement of the antitrust laws would be seriously undermined if, by excessive reliance on what may only be an indication of purpose, powerful retailers were allowed to escape penalties incurred by weak retailers that must join with others to achieve a similar goal. Moreover, under this rule, a dealer cartel might escape the law's net by channeling its demands through one small dealer.

Nor is the horizontal-plurality requirement justifiable as a means of preferring vertical analysis and the rule of reason to per se rules: ${ }^{118}$ avoidance of the law is no justification at all. At any rate, horizontal plurality is not the real determinant of per se unreasonableness. ${ }^{120}$ The essence of a violation of section 1 of the Sherman Act is agreement to pursue illegal conduct. ${ }^{121}$ A combination to cut a retailer off from a source of supply is not any less an illegal agreement because only one, rather than a plurality, of the parties is on the affected level. ${ }^{122}$ Nor is the effect of the combination any less harmful. A dealer's success in using the refusal-to-deal weapon to

118 See, e.g., Klor's Inc. v. Broadway-Hale Stores, Inc., 359 U.S. 207 (1959); Oreck Corp. v. Whirlpool Corp., 579 F.2d 126 (2d Cir.) (en banc), cert. denied, 439 U.S. 946 (1978); Copperstone v. Griswold Sporting Goods Co., [1977-2] Trade Cas. โ 61,623 (E.D. Mich, 1977).

119 Cf. Oreck Corp. v. Whirlpool Corp., 579 F.2d 126, 132 n.6 (2d Cir.) (en banc), cert. denied, 438 U.S. 946 (1978) (per se rule inappropriate for arrangements between one distributor and one manufacturer).

120 Even combinations involving horizontal action may not be treated as per se illegal. Rather, as in a group boycott, intent is the determinative criterion. If the boycott's purpose is anticompetitive, exclusionary, or coercive, a per se rule may be warranted. See, e.g., Smith v. Pro Football, Inc., 593 F.2d 1173, 1178 (D.C. Cir. 1978) ('[T]he hallmark of the 'group boycott' is the effort of competitors to 'barricade themselves from competition at their own level.' It is this purpose to exclude competition that has characterized the Supreme Court's decisions involing the group boycott per se rule.") (quoting L. SuLITVAN, supra note 8, at 245) (footnotes omitted); E.A. McQuade Tours, Inc. v. Consolidated Air Tour Manual Comm., 467 F.2d 178 (5th Cir. 1972), cert. denied, 409 U.S. 1109 (1973) (applying rule of reason to boycotts); L. Sullrvan, supra note 8, at 241; Woolley, supra note 113 , at 775 .

In Joseph E. Seagram \& Sons v. Hawaiian Oke \& Liquors, Ltd., 416 F.2d 71 (9th Cir. 1969), cert. denied, 396 U.S. 1062 (1970), a terminated distributor sought application of a per se theory against two former suppliers on the ground that their action in replacing it with another distributor constituted a group boycott. The court refused to hold the arrangement per se illegal because neither the new distributor nor any of the suppliers were "primarily motivated by a desire to damage plaintiff or put it out of business." Id. 78. Per se illegality, though reserved almost exclusively for horizontal restraints, thus turns not on form but on purpose.

121 See Turner, supra note 43 , at 655-56.

122 Ford Motor Co. v. Webster's Auto Sales, Inc., 361 F.2d 874, 878 (1st Cir. 1966) (vertical agreement within scope of section 1 of Sherman Act); Girardi v. Gates Rubber Co., 325 F.2d 196 (9th Cir. 1963) (finding that combination between one manufacturer and one distributor might be illegal). 
strike at a competitor depends on enlisting the cooperation of their mutual supplier, not other competing dealers. ${ }^{123}$

Perhaps the clearest and most serious conflict between Cernuto and Oreck is to be found in the Second Circuit's second groundjustification of vertical analysis by labeling the challenged conduct an attempt to establish an exclusive distributorship. ${ }^{124}$ The right of a manufacturer to establish an exclusive distributorship is unquestioned. ${ }^{25}$ Courts have advised disgruntled terminated dealers that an exclusive distributorship is simply not an antitrust violation, even if the dealer's business may thereby have been severely damaged or destroyed. ${ }^{126}$ Nevertheless, Oreck has taken this doctrine beyond its established reach. There, the exclusive-distributorship paradigm was applied to a case in which exclusivity was achieved by terminating the sole competitor of the benefitted and instigating dealer. ${ }^{127}$ This is a rare and possibly unsound approach. In the vast majority of cases, courts have approved exclusive distributorships only when a manufacturer replaced an existing distributor with one that had not previously been a competitor in that market or product line. ${ }^{128}$ 677.

123 See L. Sulurvan, supra note 8, at 260; Buxbaum, supra note 113 , at 675 ,

124 Oreck Corp. v. Whirlpool Corp., 579 F.2d 126, 130 (2d Cir.) (en banc), cert. denied, 439 U.S. 946 (1978).

125 See, e.g., United States v. Arnold, Schwinn \& Co., 388 U.S. 365, 376 (1967), overruled on other grounds, Continental T.V., Inc. v. GTE Sylvania Inc., 433 U.S. 36 (1977); Dougherty v. Continental Oil Co., 579 F.2d 954, 961 n.3 (5th Cir. 1978); GTE Sylvania Inc. v. Continental T.V., Inc., 537 F.2d 980, 988 (9th Cir. 1976), affd, 433 U.S. 36 (1977); Burdett Sound, Inc. v. Altec Corp., 515 F.2d 1245, 1249 (5th Cir. 1975); Joseph E. Seagram \& Sons v. Hawaiian Oke \& Liquors, Ltd., 416 F.2d 71, 76 (9th Cir. 1969), cent. denied, 396 U.S. 1062 (1970). 1975).

126 E.g., Burdett Sound, Inc. v. Altec Corp., 515 F.2d 1245, 1249 (5th Cir.

127 See text accompanying note 94 supra.

128 See, e.g., Universal Brands, Inc. v. Phillip Morris, Inc., 546 F.2d 30 (5th Cir. 1977) (substitution of exclusive distributor); Burdett Sound, Inc. v. Altec Corp., 515 F.2d 1245 (5th Cir. 1975) (substitution); Ark Dental Supply Co. v. Cavitron Corp., 461 F.2d 1093 (3d Cir. 1972) (substitution of distributors); Bushie v. Stenocord Corp., 460 F.2d 116 (9th Cir. 1972) (vertical integration by manufacturer); Joseph E. Seagram \& Sons v. Hawaiian Oke \& Liquors, Ltd., 416 F.2d 71 (9th Cir. 1969), cert. denied, 396 U.S. 1062 (1970) (substitution of distributors); Ace Beer Distribs., Inc. v. Kohn, Inc., 318 F.2d 283 (6th Cir.), cert. denied, 375 U.S. 922 (1963) (substitution of distributors); Fleischmann Distilling Corp. v. Distillers Co., 395 F. Supp. 221, 227 n.11 (S.D.N.Y. 1975) (substitution of distributors); Bay City-Abrahams Bros. v. Estee Lauder, Inc., 375 F. Supp. 1206 (S.D.N.Y. 1974) (terminated dealer not competing with substituted dealer in relevant product line). Cf. Quality Mercury, Inc. v. Ford Motor Co., 542 F.2d 466 (8th Cir. 1976) (dealer veto power over new distribution); Top-All Varieties, Inc. v. Hallmark Cards, Inc., 301 F. Supp. 703 (S.D.N.Y. 1969) (manufacturer abiding by exclusive-distributorship agreement). But see Packard Motor Car Co. v. Webster Motor Car Co., 243 F.2d 418 (D.C. Cir.), cert. denied, 355 U.S. 822 (1957); Schwing Motor Co. v. Hudson Sales Corp., 138 F. Supp. 899 (D. Md.), aff'd, 239 F.2d 176 (4th Cir. 1956), cert. denied, 355 U.S. 823 (1957). 
This distinction is important. An exclusive distributorship, a promise by the supplier not to sell to any dealer other than the exclusive dealer in a designated territory, is in effect a vertical territorial restriction on intrabrand competition..$^{129}$ From the manufacturer's viewpoint, an exclusive distributorship, like other vertical restraints, may enable it to induce a dealer to take on its product line, promote it vigorously, and provide customer services. ${ }^{130}$ From the dealer's vantage point, an exclusive distributorship is an effective means of escaping competition from other dealers. ${ }^{132}$

In a typical exclusive-distributorship case, existing dealers are replaced by a new dealer, with which the terminated dealers have never competed for customers. But they are in competition for the manufacturer's business: dealers trying to win an exclusive distributorship attempt to deprive others of that privilege by offering the best terms. ${ }^{132}$ Both intent and effect are procompetitive. Replacing one distributor with another does not reduce existing intrabrand competition, ${ }^{133}$ and a rational manufacturer will choose the best offer. By making its distribution system more efficient, the manufacturer stimulates interbrand competition. Furthermore, because the manufacturer is not dependent upon the new distributor at the time of negotiations, the possibility of dealer coercion is remote. Vertical analysis is therefore appropriate for such typical exclusive-distributorship practices.

The situation is different when the terminated distributor was a competitor of the newly established exclusive distributor. ${ }^{134}$ First,

129 See L. Sulrivan, supra note 8, at 423-24.

130 Id. 424; See Note, Restricted Channels of Distribution Under the Sherman Act, 75 Harv. I. REv. 795, 805 (1962).

131 "Since the immediate object of an exclusive dealership is to protect the dealer from competition in the manufacturer's product, it is likely to be the dealer who asks for it." Packard Motor Car Co. v. Webster Motor Car Co., 243 F.2d 418, 421 (D.C. Cir.), cert. denied, 355 U.S. 822 (1957). See L. SulurvaN, supra note 8, at 425; Note, Restricted Channels of Distribution Under the Sherman Act, 75 HARv. L. REv. 795, 809 (1962).

132 See Woolley, supra note 113, at 796-97; Note, Restricted Channels of Distribution Under the Sherman Act, 75 HaRv. L.Rev. 795, 806-08 (1962) (contractual obligations demanded by manufacturer in return for exclusive distributorship); $c f$. Joseph E. Seagram \& Sons v. Hawaiian Oke \& Liquors, Ltd., 416 F.2d 71, 78 (9th Cir. 1969), cert. denied, 396 U.S. 1062 (1970) (when previously exclusive distributor was replaced by a new distributor, the court looked upon plaintiff's past performance, the supplier's purpose in improving his product's distribution, and the new dealer's aggressiveness as the "essence of competition").

133 See Ace Beer Distribs., Inc. v. Kohn, Inc., 318 F.2d 283, 286-87 (6th Cir.), cert. denied, 375 U.S. 922 (1963); L. SullivaN, supra note 8, at 427; Elias, supra note 113 , at 473 n.112.

134 The Second Circuit admitted that "this case does not fit exactly into the dealer substitution line of cases." Id. 132 n.6. 
with one less active distributor, intrabrand competition is reduced. Second, and more important, as Professor Sullivan notes, "when an existing dealer enlists the manufacturer to choke off one of the dealer's competitors, although the 'agreement' which enables Section 1 to be invoked is vertical, the restraint thereby achieved is horizontal in its impact; it is an attack by one dealer against another." 135 In either case, of course, the terminated dealer is injured. Significant, however, is the absence in the latter case of the type of procompetitive purpose ${ }^{136}$ that may lead to enhanced interbrand competition and justify vertical analysis. In this absence, horizontal analysis is proper. ${ }^{137}$

Application of a rule of reason to the facts of Oreck is thus not justifiable by either a horizontal-plurality requirement or by the exclusive distributorship cases: the Third Circuit's approach in Cernuto is preferable.

\section{Applying Cernuto: Distinguishing Horizontal from VERTICAL RESTRAINTS}

Cernuto was decided on a motion for summary judgment, ${ }^{138}$

Furthermore, the major case supporting the Second Circuit's approach, Packard Motor Car Co. v. Webster Motor Car Co., 243 F.2d 418 (D.C. Cir.), cert. denied, 355 U.S. 822 (1957), is distinguishable. There, the largest dealer of Packard cars in Baltimore told Packard that it was losing money and threatened to quit unless it was granted an exclusive distributorship. Packard complied and terminated plaintiff's distributorship, a step which the court held per se legal. The result in Packard can be explained not only in terms of exclusive distributorships, but also by the "failing company" doctrine, a defense originating in merger cases that provides for a degree of judicial discretion in enforcing the antitrust laws. See I. Schwariz \& J. FlynN, supra note 6, at 172; L. Sulurvan, supra note 8 , at $\$ 204$ (g). For examples of characterizations of Packard as a "failing company" case, see White Motor Co. v. United States, 372 U.S. 253, 269-70 n.8 (1963) (Brennan, J., concurring); Cernuto, Inc. v. United Cabinet Corp., 595 F.2d 164, 169 (3d Cir. 1979).

135 L. Sullivan, supra note 8, at 429.

136 The court in Oreck Corp. v. Whirlpool Corp. did not rule on the possibility of an inquiry into anticompetitive purpose or effect, 579 F.2d 126, 132 n.6 (2d Cir.) (en banc), cert. denied, 439 U.S. 946 (1978). But by the court's reasoning this inquiry would be undertaken within the framework of vertical analysis and could produce the distorting results discussed in text accompanying notes 88-89 supra.

137 See text accompanying notes 83-90 supra.

138Permitting a vertical arrangement to be analyzed primarily in terms of its horizontal impact and purpose will probably improve a plaintiff's chances of surviving summary judgment, if only for the reason that a per se rule is more easily applied to horizontal restraints. See Continental T.V., Inc. v. GTE Sylvania Inc., 433 U.S. 36, 58 n.28 (1977) (horizontal restraints remain subject to per se rule); Elias, supra note 113, at 443; Comment, A Proposed Rule of Reason Analysis for Restrictions on Distribution, 47 FordhaM L. Rev. 527, 536 (1979). Characterizing vertical arrangements as horizontal restraints does not, however, mandate that every case go to trial. The discovery process and pretrial record may permit a trial judge to dispose of meritless claims notwithstanding an operative per se rule. See 
and the court thus assumed ${ }^{139}$ (1) that an agreement existed between the defendants, (2) that Famous's conduct was the cause of United's decision to terminate Cernuto, and (3) that Famous acted with the purpose of avoiding the threat of direct price competition from Cernuto. ${ }^{140}$ This Comment has up to this point made a similar assumption: that a dealer-prescribed vertical restraint can be readily differentiated from a unilateral decision by a manufacturer. Without these assumptions, guidelines must be formulated to facilitate the factfinder's task of distinguishing truly vertical restraints from those tainted by horizontal purpose.

The test in Cernuto was expressed in terms of causation-did Famous bring about Cernuto's termination? 141 The practical problem is to formulate a jury instruction that specifically describes the degree of causation necessary for a violation. Such an instruction should also describe a standard by which businessmen can govern their actions.

A recent district court opinion provides a good starting point. In Edward J. Sweeney of Sons v. Texaco, Inc., ${ }^{142}$ Sweeney, a gaso-

Aladdin Oil Co. v. Texaco, Inc., 603 F.2d 1107, 1111 (5th Cir. 1979); Lupia v. Stella D'Oro Biscuit Co., 586 F.2d 1163, 1167 (7th Cir. 1978) ("[M]ere recitation of antitrust claims in a complaint does not render that complaint immune from summary disposition, if uncontradicted facts show otherwise.").

Even so, courts faced with cases similar to Cernuto should err if at all in favor of a trial. The facts necessary to a terminated dealer's theory are eminently well-suited to resolution by a jury: "[T] here is one task that judges and juries, informed through the adversary system, may really be good at. It is identifying the pernicious in human affairs." L. ScHWARTz \& J. FIYNN, supra note 6, at 125 (quoting unedited draft of Sullivan, Economics and More Humanistic Disciplines: What Are the Sources of Wisdom for Antitrust?, 125 U. PA. L. Rev. 1214 (1977)). The crucial element is subjective: what was the source and purpose of the termination decision? As the Supreme Court has advised, in oft-quoted words:

We believe that summary procedures should be used sparingly in complex antitrust litigation where motive and intent play leading roles, the proof is largely in the hands of the alleged conspirators, and hostile witnesses thicken the plot. It is only when the witnesses are present and subject to cross-examination that their credibility and the weight to be given their testimony can be appraised.

Poller v. Columbia Broadcasting Sys., Inc., 368 U.S. 464, 473 (1962) (emphasis added) (footnotes omitted). But see 2 P. AREedA \& D. TURNer, ANTrtrust Liaw I $316 \mathrm{~b}$, at 62 (1978), noting that "the often quoted general language of Poller is in itself no barrier to summary judgment. [The Court only seemed to say that] complex antitrust cases frequently involve material disputes of fact that should not be resolved prematurely."

139 In ruling on a motion for summary judgment, a court is required to view the facts in the light most favorable to the nonmoving party. See, e.g., Poller v. Columbia Broadcasting Sys., Inc., 368 U.S. 464, 473 (1962).

140 Cernuto, Inc. v. United Cabinet Corp., 595 F.2d 164, 165 (3d Cir. 1979). 141 Id. 165 ("[W]e must infer that Famous' conduct was the cause of United's decision to terminate Cernuto's supply .....").

142 [1979-2] Trade Cas. đf 62,951 (E. D. Pa. 1979). 
line retailer, sought to apply Cernuto to its case. Sweeney brought suit when Texaco, its supplier, increased the price of gasoline sold to Sweeney and thus forced Sweeney to raise its price at the pumps. Sweeney was a discounter that cut its costs and prices by offering only an austere "gas-and-go" service at its stations. This policy greatly increased its sales and led other branded Texaco retailers to complain to Texaco of the resulting harm to their businesses. Sweeney alleged that Texaco's price increase was in response to these complaints and was an attempt to stablize resale prices at a level acceptable to the complaining retailers. The only substantial evidence offered by Sweeney to prove a conspiracy was that Texaco had received complaints from Sweeney's competitors. ${ }^{143}$ Texaco, on the other hand, was able to advance legitimate reasons for its actions. ${ }^{144}$

After extensive discovery and trial, directed verdict was granted for defendants. According to the judge, if Sweeney had proven a combination or conspiracy, the conduct would have been a horizontal restraint illegal per se under Cernuto. ${ }^{145}$ But the judge refused to allow an inference of concerted action from the mere receipt by Texaco of complaints from Sweeney's competitors:

The courts agree that where the communications show only the manufacturer's knowledge they cannot serve as the basis for an inference of a combination. Whereas if the communications show knowledge plus an intent to act on the complaint, they can. ... It is only if he acts upon the complaints, thereby becoming more than a passive recipient, that he turns into a co-conspirator and violates the antitrust laws. ${ }^{146}$

This Comment does not take issue with the judge's ruling that mere receipt of complaints cannot suffice to establish a combination or conspiracy. ${ }^{147}$ To hold otherwise clearly would be inequitable. ${ }^{148}$

${ }^{143}$ Id. 79,418 .

144 Id. 79,419 .

145 Id. 79,420 .

${ }^{146} I d$. (citations omitted).

147 See Westinghouse Elec. Corp. v. CX Processing Labs., Inc., 523 F.2d 668 (9th Cir. 1975); Klein v. American Luggage Works, Inc., 323 F.2d 787 (3d Cir. 1963); Carr Elec. Corp. v. Sony Corp. of America, 472 F. Supp. 9 (N.D. Cal. 1979); Carbon Steel Prods. Corp. v. Alan Wood Steel Co., 289 F. Supp. 584 (S.D.N.Y. 1968).

148 "[T] d draw an inference of combination between the maker and the recipient of a complaint from the mere receipt of a complaint would be somewhat like holding that the subject of an attempted bribe is guilty of bribery." Edward J. 
More susceptible to criticism, however, is the judge's dictum that if the supplier had merely acted upon the complaints, the conduct would thereby have been brought within the scope of section 1 and under Cernuto would constitute a horizontal restraint. The judge's language-cacts upon the complaints"-is too vague, and gives too little weight to the supplier's legitimate explanations for his actions, to justify horizontal characterization. The dictum in Sweeney misperceives the realities of the interaction of interests in a distribution channel. The manufacturer's procompetitive goals for his distribution channel are often achieved only by satisfying the anticompetitive desires of his distributors. ${ }^{149}$ A manufacturer may have numerous legitimate reasons for terminating a dealer ${ }^{150}$ that coincide with the illegitimate reasons of the distributor demanding termination of its competitor. For instance, violation of a distribution contract may come to the manufacturer's attention only through the complaint of another dealer that maintains a close and jealous watch upon its rivals' activities. ${ }^{151}$ Yet, if the Sweeney dictum is given its full force, a manufacturer's actions on this complaint would meet the requisite concert of action under section 1 , and the restraint would be considered horizontal-even though the manufacturer was only trying to maintain control over its distribution channel.

The court in Cernuto had already assumed the existence of concerted action before it undertook to characterize the agreement as effecting a horizontal restraint. The opinion is not so much concerned with the agreement to restrain as with the reasons underlying the restraint. ${ }^{152}$ Although application of Cernuto should incorporate Sweeney's reasoning regarding the requirements of section 1, a court should demand more before considering challenged conduct horizontal. The test should be formulated with an eye towards avoiding unduly impinging upon a manufacturer's ability and discretion to make marketing decisions while also avoiding eviscerating a dealer's cause of action.

Sweeney \& Sons v. Texaco, Inc., [1979-2] Trade Cas. [62,951, at 79,435 n.32 (E.D. Pa. 1979).

${ }^{149}$ See Note, Restricted Channels of Distribution Under the Sherman Act, 75 HARv. L. Rev. 795, 825 (1962).

150 See, e.g., Continental T.V., Inc. v. GTE Sylvania Inc., 433 U.S. 36 (1977) (enforcement of location restriction by termination).

151 Indeed, one of the manufacturer's most valuable sources of information about the operation of its distribution channel is communications from its dealers. See Comment, Vertical Agreements to Terminate Competing Distributors: Oreck Corp. v. Whirlpool Corp., 92 Harv. L. REv. 1160, 1169 (1979).

152 See text accompanying notes $39-47$ supra. 
These goals can be achieved by implementing a "but for" test ${ }^{153}$ with the burden of persuasion on the manufacturer. The challenged conduct would be characterized as horizontal only if the manufacturer would not have pursued the action but for the complaints or agitation of the competing dealer or dealers. A preliminary finding, as required by Sweeney, that the manufacturer acted upon the complaint would raise a presumption of concerted action, which could be rebutted only by proof of a convincing and legitimate reason to show that, under the circumstances, the termination was inevitable. ${ }^{154}$ This evidence might include explanations such as the dealer's violation of a marketing agreement, protection of product integrity, unsatisfactory dealer performance, instability of the dealer's business, the dealer's dishonesty, shortage of supply, or reorganization of the marketing system. ${ }^{155}$

One business reason, in particular, should not be considered legitimate. A manufacturer may find cutting off a distributor in his interest in order to retain the business of the distributor demanding the termination. ${ }^{156}$ Oreck represents a good example of this situation: Whirlpool could not afford to lose the patronage of Sears, which bought ninety percent of all Whirlpool-made vacuum cleaners. ${ }^{157}$ Allowing a manufacturer to claim as a legitimate reason such loss minimization would serve to deliver manufacturers wholesale into the arms of anticompetitive, powerful distributors. ${ }^{158}$

153 Courts have had occasion to apply a "but for" test in considering whether legal injury resulted from antitrust law violations. E.g., Warriner Hermetics., Inc. v. Copeland Refrigeration Corp., 463 F.2d 1002, 1016 (5th Cir.), cert. denied, 409 U.S. 1086 (1972). See generally 2 P. AREeda \& D. TuRnER, ANTtTrust Law II 343-347 (1978); 16N J. VoN Kalinowski, ANTItrust Laws and Trade REgULATIONS $\$ 115.02(1)(b)$ (Business Organizations Series 1978).

154 A distribution agreement will permit termination for reasons other than cause, or even at the supplier's whim, but the supplier's rights under the contract are not a defense to an antitrust violation. See Poller v. Columbia Broadcasting Sys., Inc., 368 U.S. 464, 468-69 (1962); Pitchford v. PEPI, Inc., 531 F.2d 92 (3d Cir.), cert denied, 426 U.S. 935 (1976); Osborn v. Sinclair Refining Co., 324 F.2d 566, 575 n.17 (4th Cir. 1963); Interphoto Corp. v. Minolta Corp., 295 F. Supp. 711, 723 (S.D.N.Y.), affd per curiam, 417 F.2d 621 (2d Cir. 1969). Cf. Cernuto, Inc. v. United Cabinet Corp., 595 F.2d 164, 170 (3d Cir. 1979) (sudden breach of a recent contract was relevant evidence of the true purpose of the termination).

155 See Vertical Restrictions, supra note 6, at 56-57; Bohling, supra note 113 , at 1220 .

156 See Mallen, supra note 67 , at 124 .

157 See note 94 supra.

158 "[I]f the manufacturer drops the customer it regards as less valuable to satisfy the one it regards as more valuable, it is acting with no different or better sanction than that of any other seller which when threatened by a buyer (or a group of buyers), drops a competitor of the buyer (or group)." L. Sulurvan, supra note 8 , at 428 . 
The absence of a legitimate business reason for a termination, combined with proof that a competing distributor played a large role in the decision, "renders reasonable the inference of anticompetitive motive or effect." 150 When the decision is not unilateral, in view of the possible anticompetitive purpose or effect, it is proper to demand from the manufacturer a convincing justification..$^{100}$ The rebuttable presumption and the requirement that the business reason be convincing as well as legitimate are also justified, if not required, by the possibility that a manufacturer's file will be created or doctored in order to paint a picture of an innocent and efficiency-minded management. ${ }^{161}$ Demanding any less may well reduce Cermuto to only a topic for law review commentary and induce frustrated courts to apply something closer to a material-cause test fraught with the drawbacks of the Sweeney dictum.

\section{ConcLusron}

By reversing prior case law and holding vertical restraints subject to a rule of reason, Sylvania validly incorporated the realities of modern marketing into the antitrust laws. But Sylvania cannot serve as a screen for dealer abuse of a manufacturers marketing powers. If courts are to avoid exalting form over substance, they should question whether the arrangement at issue is truly a vertical restraint within the contemplation of Sylvania-a restraint imposed by the manufacturer on intrabrand competition for the purpose of enhancing interbrand competition. Dealer-prescribed restraints must be treated for what they are-horizontal restraints not mitigated by vertical form.

To discover the true nature of a restraint on intrabrand competition, courts should inquire into the source and purpose of the decision to restrain. A vertical arrangement may be characterized as horizontal if the factfinder finds that (1) but for the dealer's pressure on a manufacturer to eliminate the competition of another dealer, the restraint would not have occurred; and (2) the manufacturer can assert no convincing legitimate business reason of its own for the restraint.

159 Quality Mercury, Inc. v. Ford Motor Co., 542 F.2d 466, 470 (8th Cir. 1976), cert. denied, 433 U.S. 914 (1977).

$180 \mathrm{Cf}$. Note, Restricted Channels of Distribution Under the Sherman Act, 75 HaRv. L. Rev. 795, 808-09 (1962) (dealers' interests in exclusive distributorships, though perhaps coinciding with those of suppliers, are usually anticompetitive).

161 See L. Scewartz \& J. FirnN, supra note 6, at 632-40 (materials and notes on professional ethics and antitrust counseling). 